\title{
Metathesis of carbon dioxide and phenyl isocyanate catalysed by group(IV) metal alkoxides: An experimental and computational study
}

\author{
AKSHAI KUMAR and ASHOKA G SAMUELSON* \\ Department of Inorganic and Physical Chemistry, Indian Institute of Science, Bangalore 560 012, India \\ e-mail: ashoka@ipc.iisc.ernet.in
}

MS received 8 October 2010; accepted 6 December 2010

\begin{abstract}
The insertion reactions of zirconium(IV) $n$-butoxide and titanium(IV) $n$-butoxide with a heterocumulene like carbodiimide, carbon dioxide or phenyl isocyanate are compared. Both give an intermediate which carries out metathesis at elevated temperatures by inserting a second heterocumulene in a head-to-head fashion. The intermediate metallacycle extrudes a new heterocumulene, different from the two that have inserted leading to metathesis. As the reaction is reversible, catalytic metathesis is feasible. In stoichiometric reactions heterocumulene insertion, metathesis and metathesis cum insertion products are observed. However, catalytic amounts of the metal alkoxide primarily led to metathesis products. It is shown that zirconium alkoxides promote catalytic metathesis (isocyanates, carbon dioxide) more efficiently than the corresponding titanium alkoxide. The difference in the metathetic activity of these alkoxides has been explained by a computational study using model complexes $\mathrm{Ti}(\mathrm{OMe})_{4}(\mathbf{1 b T i})$ and $\mathrm{Zr}(\mathrm{OMe})_{4}(\mathbf{1 b Z r})$. The computation was carried out at the B3LYP/LANL2DZ level of theory.
\end{abstract}

Keywords. Aryl isocyanates; insertion; metathesis; titanium $n$-butoxide; zirconium $n$-butoxide.

\section{Introduction}

Reactions converting carbon dioxide to organic compounds not only help in scavenging carbon dioxide which is a green house gas, but also provide easy access to many useful compounds. Metathesis of carbon dioxide and carbodiimide is one such conversion. While metathesis of cumulenes is not known, the metathesis of heterocumulenes is better explored. Carbodiimide metathesis is catalysed by a number of complexes leading to formation of unsymmetrical carbodiimides. ${ }^{1}$ Group 14 compounds are known to catalyse metathesis of phenyl isocyanates to give $\mathrm{N}, \mathrm{N}^{\prime}$ diphenyl carbodiimides and carbon dioxide. ${ }^{2}$ The reverse reaction, metathesis of carbon dioxide with isocyanides ${ }^{3}$ and carbodiimide ${ }^{4}$ leading to formation of isocyanates has also been demonstrated. Recently, Meyer and co-workers have shown that mid and high valent uranium amido and imido derivatives promote multiple bond metathesis with carbon dioxide to give isocyanates and uranium oxo complexes. ${ }^{5}$

\footnotetext{
*For correspondence
}

In the case of titanium(IV) alkoxides, it has been shown that metathesis cum insertion products can be isolated when stoichiometric amounts of aryl isocyanates are reacted with them in refluxing toluene. ${ }^{4 \mathrm{e}}$ Double insertion of aryl isocyanate in a head-to-head fashion with subsequent elimination of carbon dioxide was said to be responsible for the observed metathesis. The reaction was shown to be reversible; forming unsymmetrical carbodiimides when carried out with a mixture of different aryl isocyanates. Contrary to the substituent effects in the head-to-tail double insertion reactions observed at room temperature, ${ }^{6 a}$ electron donating groups favoured the metathesis reaction. It was also observed that steric factors slowed down the metathesis reaction which is similar to that observed with insertion reactions. The metathesis reactions of heterocumulenes have been explored extensively only with titanium(IV) isopropoxide.

No comparison of the metathetic reactivity of a common heterocumulene with titanium or with other zirconium(IV) alkoxides is available. There have been several examples where $\mathrm{Ti}$ and $\mathrm{Zr}$ behave differently towards the same ligand system ${ }^{6 \mathrm{~b}, 7}$ and so 
there is every possibility that different reactivity would be exhibited by $\mathrm{Zr}$ towards metathesis. Hence it would be interesting to know whether such reactivity differences can be used to control the metathesis reactivity and how a change in the alkoxide from isopropoxide to butoxide affects metathesis. In this paper, we report the metathesis reaction of phenyl isocyante (PhNCO) catalysed by titanium(IV) $n$-butoxide and zirconium(IV) $n$-butoxide. There are distinct differences in the reactivity of phenyl isocyante with group(IV) metal alkoxides at room temperature and at elevated temperatures. Computational studies performed on model complexes $\mathrm{Ti}(\mathrm{OMe})_{4}$ and $\mathrm{Zr}(\mathrm{OMe})_{4}$ at the $\mathrm{B} 3 \mathrm{LYP} /$ LANL2DZ level of theory using the Gaussian 03 package, explain these differences very well.

\section{Experimental}

\subsection{General}

All manipulations were carried out under an inert atmosphere of dry argon using a standard double manifold. Toluene and tetrahydrofuran were freshly distilled from sodium/benzophenone prior to use. Zirconium(IV) $n$-butoxide ( $84 \mathrm{wt} \%$ in 1-butanol), titanium(IV) $n$-butoxide, titanium(IV) isopropoxide and phenyl isocyanate were procured from Aldrich U.S.A. Zirconium(IV) $n$-butoxide solution was evaporated to dryness under vacuum at $110^{\circ} \mathrm{C}$. Commercial grade carbon dioxide was obtained from Bhuruka Gas India. It was dried by passing through a column containing alternative layers of fused calcium chloride and $\mathrm{P}_{2} \mathrm{O}_{5}$ prior to use. Diphenyl carbodiimide was synthesized by the literature procedure. $^{8 \mathrm{a}}$

\subsection{Physical measurements}

${ }^{1} \mathrm{H}$ NMR, ${ }^{13} \mathrm{C}\{\mathrm{H}\}$ NMR, inverse gated decoupled ${ }^{13} \mathrm{C}$ NMR were recorded on Bruker AMX 400 operating at $400 \mathrm{MHz}$ for ${ }^{1} \mathrm{H}$ NMR and $100 \mathrm{MHz}$ for ${ }^{13} \mathrm{C}$ NMR, with tetramethylsilane as internal reference. All spectra were recorded in $\mathrm{CDCl}_{3}$.

\subsection{General procedure for the metathesis of phenyl isocyanate}

To a solution of zirconium(IV) $n$-butoxide $(0.134 \mathrm{~g}$, $0.35 \mathrm{mmol}$ ) dissolved in $15 \mathrm{ml}$ toluene, phenyl isocyanate $(0.38 \mathrm{ml}, 3.5 \mathrm{mmol})$ was added. The mixture was stirred and refluxed for $48 \mathrm{~h}$. The solvent was then evaporated to dryness under vacuum. The mixture was worked up by addition of a stoichiometric amount of water to precipitate out $\mathrm{ZrO}_{2}$, followed by extraction of the organic fraction with dichloromethane and removal of the solvent from the organic fraction. The yield of diphenyl carbodiimide was calculated by inverse gated decoupled ${ }^{13} \mathrm{C}$ NMR and ${ }^{1} \mathrm{H}$ NMR using ferrocene as an internal standard. The yield of diphenyl carbodiimide was further verified by isolating it as diphenyl urea after hydrolysis.

The organic fraction obtained in the catalytic metathesis reaction was run on preparative TLC plates using hexane, toluene and ethyl acetate in the ratio 7:3:1 as eluent. Compound 2 separated out as diphenyl urea in this method, while compound $\mathbf{4}$ was obtained in the pure form and compounds $\mathbf{3}$ and $\mathbf{6}$ remained as a mixture. This mixture was run on preparative TLC plates using $1 \%$ ethyl acetate in petroleum ether as eluent, where compounds $\mathbf{3}$ and $\mathbf{6}$ were obtained in the pure form.

\subsection{Compound $\mathbf{3}^{8 \mathrm{~b}}$}

Butyl $N$-phenylcarbamate: $\mathrm{mp}=62-63 \cdot 5^{\circ} \mathrm{C} .1 \mathrm{H}$ NMR $(400 \mathrm{MHz}) \delta 7.37(d, 2 \mathrm{H}, J=8 \mathrm{~Hz}), \delta 7.30(t, 2 \mathrm{H}$, $J=8 \mathrm{~Hz}), \delta 7.05(t, 1 \mathrm{H}, J=7.3 \mathrm{~Hz}), \delta 6.63(s, 1 \mathrm{H}, \mathrm{NH})$, $\delta 4.17(t, 2 \mathrm{H}, J=6.7 \mathrm{~Hz}), \delta 1.65(m, 2 \mathrm{H}), \delta 1.42(m$, $2 \mathrm{H}), \delta 0.95(t, 3 \mathrm{H}, J=7 \cdot 3 \mathrm{~Hz}) .13 \mathrm{C}$ NMR $(100 \mathrm{MHz})$ $\delta 153 \cdot 78, \delta 138 \cdot 02, \delta 129 \cdot 10, \delta 123 \cdot 37, \delta 118 \cdot 63, \delta$ $65 \cdot 18, \delta 31 \cdot 02, \delta 19 \cdot 14, \delta 13 \cdot 30$.

\subsection{Compound $\mathbf{6}^{8 \mathrm{c}}$}

Butyl 2,4-diphenylallophanate: $\mathrm{mp}=64 \cdot 5-65 \cdot 5^{\circ} \mathrm{C} .{ }^{1} \mathrm{H}$ NMR $(400 \mathrm{MHz}) \delta 10.91(s, 1 \mathrm{H}, \mathrm{NH}), \delta 7.53(d, 2 \mathrm{H}$, $J=7.6 \mathrm{~Hz}), \delta 7.41(m, 3 \mathrm{H}), \delta 7.31(t, 2 \mathrm{H}, J=7.6 \mathrm{~Hz}), \delta$ $7.22(d, 2 \mathrm{H}, J=7.6 \mathrm{~Hz}), \delta 7.09(t, 1 \mathrm{H}, J=7.6 \mathrm{~Hz}), \delta$ $4.15(t, 2 \mathrm{H}, J=6.8 \mathrm{~Hz}), \delta 1.48(\mathrm{~m}, 2 \mathrm{H}), \delta 1.18(\mathrm{~m}, 2$ $\mathrm{H}), \delta 0.82(t, 3 \mathrm{H}, J=7 \cdot 6 \mathrm{~Hz}) .{ }^{13} \mathrm{C}$ NMR $(100 \mathrm{MHz}) \delta$ $156 \cdot 08, \delta 151 \cdot 58, \delta 137 \cdot 77, \delta 137 \cdot 10, \delta 128 \cdot 96, \delta$ $128 \cdot 70, \delta 128 \cdot 26, \delta 123 \cdot 96, \delta 119 \cdot 92, \delta 67 \cdot 22, \delta 30 \cdot 31$, $\delta 18.78, \delta 13.47$. HRMS: Found $\mathrm{m} / \mathrm{z}=335.1356(\mathrm{M}+$ $\mathrm{Na})^{+}$, calcd. mass for $\mathrm{C}_{18} \mathrm{H}_{20} \mathrm{~N}_{2} \mathrm{O}_{3} \mathrm{Na}$ is 335.1372 .

\subsection{Compound 2}

$\mathrm{N}, \mathrm{N}^{\prime}$ diphenyl carbodiimide: ${ }^{1} \mathrm{H}$ NMR $(100 \mathrm{MHz}) \delta$ $7.27(t, 2 \mathrm{H}, J=7.4 \mathrm{~Hz}), \delta 7.14(d, 2 \mathrm{H}, J=7.4 \mathrm{~Hz}), \delta$ $7 \cdot 11(t, 1 \mathrm{H}, J=7 \cdot 4 \mathrm{~Hz}) .{ }^{13} \mathrm{C}$ NMR $(100 \mathrm{MHz}) \delta 138.47$, $\delta 135 \cdot 21, \delta 129 \cdot 42, \delta 125 \cdot 53, \delta 124 \cdot 15$. 


\subsection{Compound 4}

Carbamimidic acid, N,N'-diphenyl; $n$-butyl ester: ${ }^{1} \mathrm{H}$ NMR (400 MHz) $\delta 7.30(m, 5 \mathrm{H}), \delta 7.03(m, 5 \mathrm{H}), \delta$ $5.83(s, 1 \mathrm{H}, \mathrm{NH}), \delta 4.35(t, 2 \mathrm{H}, J=6.8 \mathrm{~Hz}), \delta 1.79(m$, $2 \mathrm{H}), \delta 1.48(m, 2 \mathrm{H}), \delta 0.97(t, 3 \mathrm{H}, J=7.2 \mathrm{~Hz}) .{ }^{13} \mathrm{C}$ NMR $(100 \mathrm{MHz}) \delta 150 \cdot 31, \delta 129.78, \delta$ 128.94, $\delta 123 \cdot 06, \delta 120 \cdot 39, \delta 66 \cdot 92, \delta 30 \cdot 84, \delta 19 \cdot 40, \delta 13.93$.

\subsection{General procedure for reactions with carbon dioxide}

Into $6 \mathrm{ml}$ toluene in a sealable vial flushed with nitrogen, carbon dioxide from a gas burette was condensed. A mixture of zirconium(IV) n-butoxide $(0.239 \mathrm{~g}, 0.6 \mathrm{mmol})$ and diphenyl carbodiimide $(0.118 \mathrm{~g}, 0.6 \mathrm{mmol})$ in $2 \mathrm{ml}$ toluene was added while maintaining the vial at liquid nitrogen temperature. The vial was subsequently evacuated and sealed. The sealed vial was heated in an oil bath maintained at $115^{\circ} \mathrm{C}$ for $48 \mathrm{~h}$. The vial was cooled, broken open and the reaction mixture evacuated to dryness under vacuum. The mixture was then worked up by addition of stoichiometric amount of water to precipitate out $\mathrm{ZrO}_{2}$, followed by extraction of the organic fraction with dichloromethane. The solvent was removed from the organic fraction and the ratio of $\mathbf{3}$ and $\mathbf{4}$ in the residue was determined by ${ }^{1} \mathrm{H}$ NMR.

\subsection{Computational details}

For theoretical studies, $\mathrm{Ti}(\mathrm{OMe})_{4}$ and $\mathrm{Zr}(\mathrm{OMe})_{4}$ were taken as model complexes in place of $\mathrm{Ti}\left(\mathrm{O}^{\mathrm{n}} \mathrm{Bu}\right)_{4}$ and $\mathrm{Zr}\left(\mathrm{O}^{\mathrm{n}} \mathrm{Bu}\right)_{4}$ where bulky ${ }^{\mathrm{n}} \mathrm{Bu}$ groups are replaced by $\mathrm{Me}$ groups for computational efficiency. All structures were optimized using the DFT method (B3LYP/ LANL2DZ), based on Becke's three-parameter functional. ${ }^{9}$ The LANL2DZ basis set uses the effective core potentials (ECP) of Hay and Wadt. ${ }^{10}$ The nature of the stationary points was characterized by vibrational frequency calculations. The Gaussian 03 program package was used for all calculations. ${ }^{11}$

\section{Results and discussions}

\subsection{Metathesis with carbon dioxide}

In an attempt to test the metathesis reaction of carbon dioxide, equimolar amounts of diphenyl carbodiimide $\mathbf{2}$ and zirconium $n$-butoxide $\mathbf{1 a Z r}$ were mixed with half a mole equivalent of carbon dioxide. The reaction mixture was heated at $110^{\circ} \mathrm{C}$ for $48 \mathrm{~h}$ in a sealed vial using toluene as solvent. The reaction mixture obtained after hydrolytic work up was found to contain significant amounts of the metathesis product, phenyl isocyanate, that was isolated as butyl $N$-phenylcarbamate, the insertion product 3 (entry1, table 1). In addition, formation of carbamimidic acid, N, N'diphenyl;n-butyl ester 4 was observed which arises from the insertion of diphenyl carbodiimide into the butoxide (entry1, table 1). Metathesis reaction occurred to a greater extent as the amount of carbon dioxide content was increased (entry 2 and 3, table 1).

The yield of the phenyl isocyanate inserted product, butyl $N$-phenylcarbamate, $\mathbf{3}$ obtained using zirconium (IV) $n$-butoxide (entry 3 , table 1 ) was more than that obtained in a similar reaction with titanium(IV) $n$ butoxide (entry 4, table 1). The metathesis reaction proceeds by the coordination of carbon dioxide to the metal followed by insertion into the $\mathrm{C}-\mathrm{N}$ bond of the carbodiimide, which then eliminates an isocyanate (scheme 1). So it is observed that metathesis of carbon dioxide is catalysed more efficiently by zirconium(IV) $n$-butoxide than by titanium(IV) $n$-butoxide. Since it has been shown that double insertion of phenyl isocyanate takes place in a head-to-tail fashion at room temperature and is more favoured with titanium, ${ }^{6 \mathrm{~b}}$ the present result is counterintuitive. It suggests that headto-head double insertion is favoured by zirconium rather than by titanium. These results were further confirmed by performing a reverse reaction with phenyl isocyanate.

\subsection{Reaction of phenyl isocyanate with titanium(IV) n-butoxide and zirconium(IV) n-butoxide}

The reaction of phenyl isocyanate (PhNCO) was carried out with sub-stoichiometric amounts of titanium(IV) $n$-butoxide $\left(\mathrm{Ti}\left(\mathrm{O}^{\mathrm{n}} \mathrm{Bu}\right)_{4}\right.$ 1aTi) and the products were analysed after work up. The crude reaction mixture was found to contain a significant amount of metathesis product N, $\mathrm{N}^{\prime}$ diphenyl carbodiimide 2 in addition to insertion products butyl $N$ phenylcarbamate 3 , butyl N, $\mathrm{N}^{\prime}$-diphenylallophanate $\mathbf{6}$ and carbamimidic acid, N,N'-diphenyl; $n$-butyl ester 4 (entry1, table 2).

The products $\mathbf{3}$ and $\mathbf{6}$ arise from the mono and double insertion of $\mathrm{PhNCO}$ into $\mathrm{Ti}\left(\mathrm{O}^{\mathrm{n}} \mathrm{Bu}\right)_{4}$ and have been reported earlier. ${ }^{6}$ Compound $\mathbf{4}$ is a metathesis cum insertion product and is formed by insertion of metathesis product $\mathbf{2}$ into 1aTi. The ratio of the products formed were determined by ${ }^{1} \mathrm{H}$ NMR and 
Table 1. Metathesis products obtained from carbon dioxide and carbodiimide mediated by titanium(IV) $n$-butoxide and zirconium(IV) $n$-butoxide.
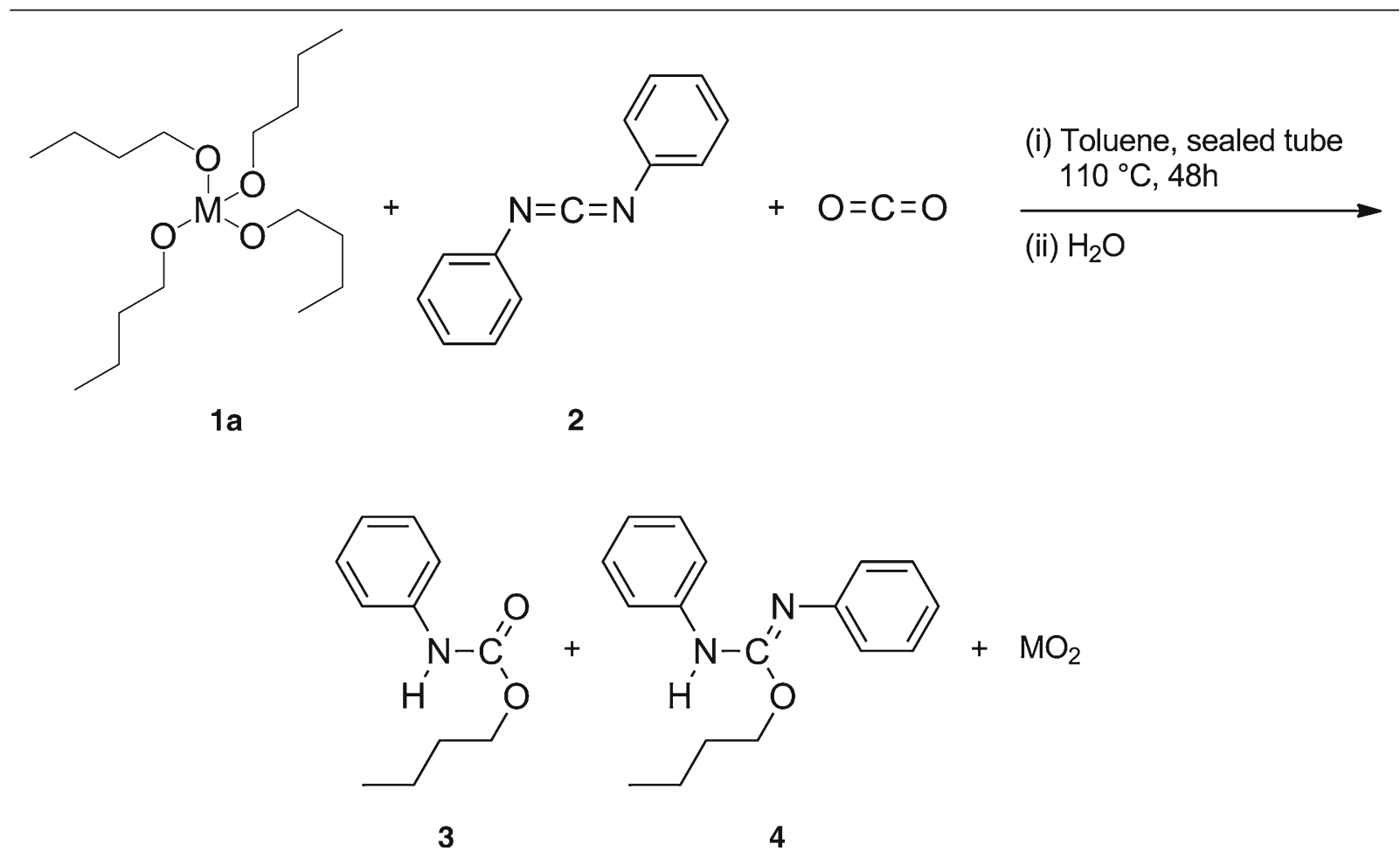

\begin{tabular}{|c|c|c|c|c|c|}
\hline \multirow{2}{*}{ Entry } & \multirow{2}{*}{ M } & \multirow{2}{*}{ Time (h) } & \multirow{2}{*}{$\mathrm{n}^{\mathrm{a}}$} & \multicolumn{2}{|c|}{ Ratio of products ${ }^{\mathrm{b}}(\%)$} \\
\hline & & & & 3 & 4 \\
\hline 1 & $\mathrm{Zr}$ & 48 & $0 \cdot 5$ & 46 & 54 \\
\hline 2 & $\mathrm{Zr}$ & 48 & $1 \cdot 0$ & 60 & 40 \\
\hline 3 & $\mathrm{Zr}$ & 48 & $3 \cdot 0$ & 89 & 11 \\
\hline 4 & $\mathrm{Ti}$ & 48 & $3 \cdot 0$ & 80 & 20 \\
\hline
\end{tabular}

inverse gated decoupled ${ }^{13} \mathrm{C}\left\{{ }^{1} \mathrm{H}\right\}$ NMR. Interestingly, there was substantial improvement in the amount of metathesis product formed when titanium(IV) $n$-butoxide was used in catalytic amounts (entry2, table 2). There was no formation of the metathesis cum insertion product 4 . Further, the amount of diphenyl carbodiimide produced was more when $\mathrm{Zr}$ was used instead of Ti (entry 3 and 4, table 2). These experiments show that zirconium(IV) $n$-butoxide and titani-
um(IV) $n$-butoxide can be utilized to convert isocyanates to carbodiimides catalytically. Clearly, zirconium(IV) $n$-butoxide is more efficient for the conversion.

\subsection{A mechanistic hypothesis}

The mechanism of the reaction essentially involves the insertion of PhNCO into metal alkoxide 1a to generate 


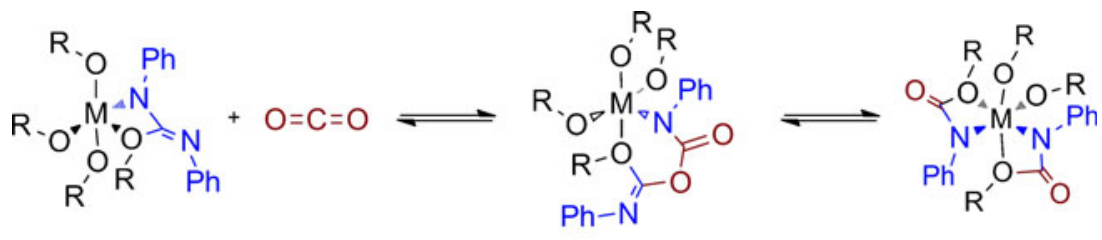

$$
\mathrm{M}=\mathrm{Ti}, \mathrm{Zr} \quad \mathrm{R}={ }^{\mathrm{n}} \mathrm{Bu}, \mathrm{Me}
$$

Scheme 1. The steps involved in the metathesis of carbon dioxide.

a metal carbamate species 7a (scheme 2). The second molecule of PhNCO can either insert in a head-to-tail fashion leading to complex 8aHT or in a head-to-head fashion giving rise to species such as $\mathbf{8 a H H}$. Elimina- tion of a molecule of carbon dioxide from the intermediate $\mathbf{8 a H H}$ leads to $\mathbf{9}$. The intermediate 9 can then extrude carbodiimide regenerating the metal alkoxide 1a.

Table 2. Products formed in the catalytic metathesis of phenyl isocyanate with $\mathrm{Ti}$ and $\mathrm{Zr}$ alkoxides.

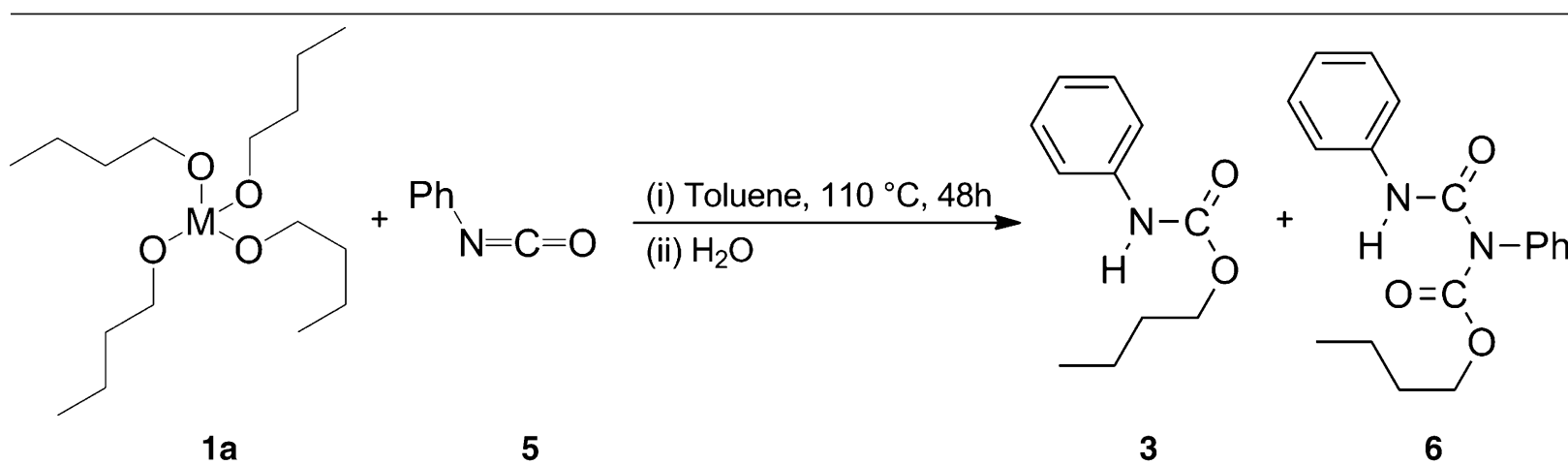

5

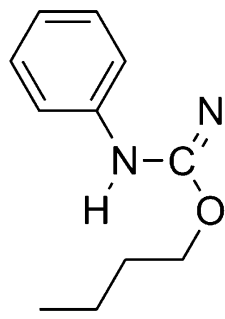

$+\mathrm{O}=\mathrm{C}=\mathrm{O}+\mathrm{MO}_{2}$

2

4

\begin{tabular}{|c|c|c|c|c|c|c|c|}
\hline \multirow{2}{*}{ Entry } & \multirow{2}{*}{ Catalyst } & \multirow{2}{*}{$\mathrm{Mol} \%$} & \multirow{2}{*}{ Time $(\mathrm{h})$} & \multicolumn{4}{|c|}{ Ratio of products ${ }^{\mathrm{a}}(\%)$} \\
\hline & & & & 2 & 3 & 4 & 6 \\
\hline 1 & $\operatorname{Ti}\left(\mathrm{O}^{\mathrm{n}} \mathrm{Bu}\right)_{4}$ & 10 & 48 & 62 & 25 & 12 & 1 \\
\hline 2 & $\mathrm{Ti}\left(\mathrm{O}^{\mathrm{n}} \mathrm{Bu}\right)_{4}$ & 1 & 48 & 90 & 6 & - & 4 \\
\hline 3 & $\mathrm{Zr}\left(\mathrm{O}^{\mathrm{n}} \mathrm{Bu}\right)_{4}$ & 10 & 48 & 88 & 9 & 2 & 1 \\
\hline 4 & $\mathrm{Zr}\left(\mathrm{O}^{\mathrm{n}} \mathrm{Bu}\right)_{4}$ & 1 & 48 & 97 & 2 & - & 1 \\
\hline
\end{tabular}

${ }^{\mathrm{a}}$ Ratio of products were determined by ${ }^{1} \mathrm{H}$ and inverse gated decoupled ${ }^{13} \mathrm{C}\left\{{ }^{1} \mathrm{H}\right\}$ NMR 


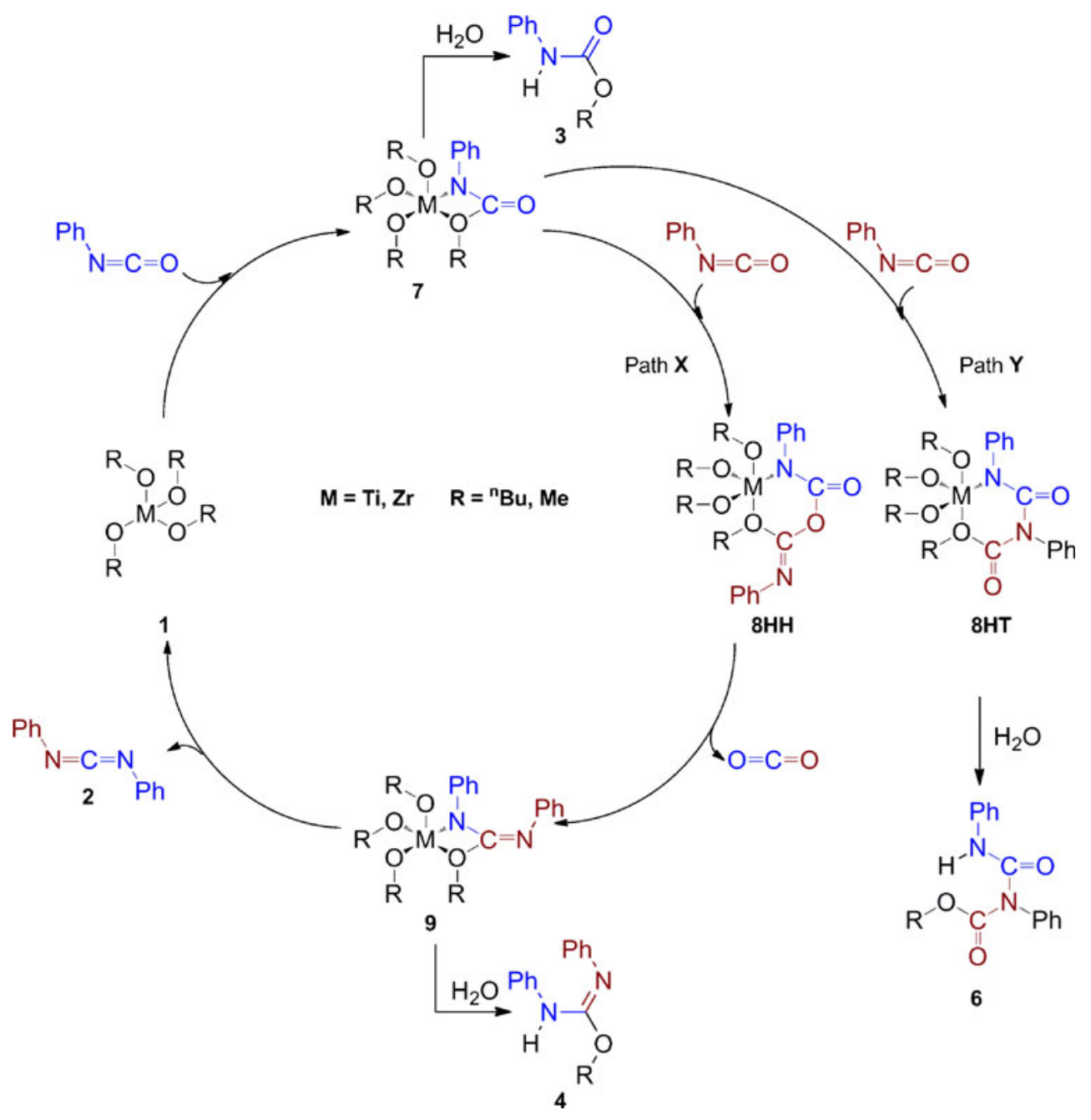

Scheme 2. Proposed mechanism for the metathesis of phenyl isocyanate mediated by $M(O R)_{4}$.

\section{Computational studies}

4.1 Comparison of energies of intermediates for the two possible insertion modes

Computational methods have been successfully used to predict the reactivity patterns in group(IV) metal alkoxides. ${ }^{6 b, 7}$ This encouraged us to seek reasons for the differences between $\mathrm{Ti}$ and $\mathrm{Zr}$ in the preference for double insertion via head-to-head and head-to-tail fashion.

The structures numbered 1 and 7 to 9 in scheme 1 were investigated. For this purpose $\mathrm{Ti}\left(\mathrm{O}^{\mathrm{n}} \mathrm{Bu}\right)_{4}(\mathbf{1 a T i})$ and $\mathrm{Zr}\left(\mathrm{O}^{\mathrm{n}} \mathrm{Bu}\right)_{4}(\mathbf{1 a Z r})$ were modelled by $\mathrm{Ti}(\mathrm{OMe})_{4}$ (1bTi) and $\mathrm{Zr}(\mathrm{OMe})_{4}(\mathbf{1 b Z r})$ where bulky ${ }^{\mathrm{n}} \mathrm{Bu}$ groups are replaced by Me groups to reduce computational load. The letters $\mathbf{a}$ and $\mathbf{b}$ are used to indicate metal complexes with $\mathrm{O}^{\mathrm{n}} \mathrm{Bu}$ ligand and $\mathrm{OMe}$ ligand respec-

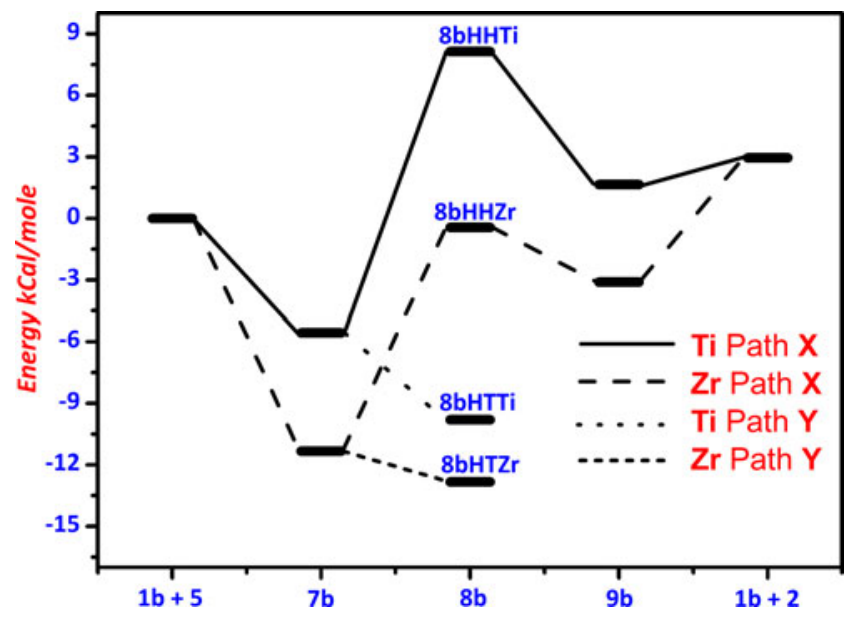

Figure 1. Computed energy profiles for the reaction of $\mathrm{PhNCO}$ with $\mathrm{M}(\mathrm{OR})_{4}\left[\mathrm{M}=\mathrm{Ti}, \mathrm{Zr}\right.$ and $\mathrm{R}={ }^{\mathrm{n}} \mathrm{Bu}$ or $\left.\mathrm{Me}\right]$ for Path $\mathbf{X}$ and Path $\mathbf{Y}$ at the B3LYP/LANL2DZ level of theory. 
tively. $\mathbf{T i}$ and $\mathbf{Z r}$ are added to indicate the metal present in the complex. HH and HT indicate the mode of insertion. For example, 8aTiHH indicates structure $\mathbf{8}$ with $\mathrm{M}=\mathrm{Ti}, \mathrm{O}^{\mathrm{n}} \mathrm{Bu}$ as the alkoxy group and a structure where $\mathrm{PhNCO}$ has undergone double insertion in a head-to-head fashion.

The reaction of the first molecule of $\mathrm{PhNCO}$ with $\mathbf{1 b T i} / \mathbf{1 b Z r}$ will generate the metal carbamate intermediate $\mathbf{7 b T i} / \mathbf{7 b Z r}{ }^{6 \mathrm{~b}}$ The second molecule of PhNCO can insert either in a head-to-head fashion to give the intermediate 8bTiHH/8bZrHH (Path X) or in a headto-tail fashion giving 8bTiHT/8bZrHT (Path Y). The double insertion proceeds only though Path $\mathbf{Y}$ at room temperature. At higher temperatures head-to-head insertion was found to occur in greater amounts through Path $\mathbf{X}$. The preference of $\mathrm{Zr}$ and Ti towards Path $\mathbf{X}$ and Path $\mathbf{Y}$ can be understood if we look into the thermodynamic stabilities of the intermediates involved (figure 1).

For both $\mathrm{Ti}$ and $\mathrm{Zr}$, path $\mathbf{Y}$ is an exothermic process whereas path $\mathbf{X}$ is endothermic. This explains why headto-head insertion is not observed at room temperature. For path $\mathbf{Y}$ it is seen that though 8bZrHT is more stabilized, the formation of $\mathbf{8 b T i H T}$ is more exothermic than $8 \mathrm{bZrHT}$. Hence the double insertion in a head-totail mode is more favoured for Ti. Path $\mathbf{X}$ is endothermic for both $\mathrm{Ti}$ and $\mathrm{Zr}$, however the formation of $\mathbf{8 b H H Z r}$ is less endothermic than that of 8bHHTi. This explains the higher efficiency of zirconium alkoxides over titanium alkoxides towards head-to-head insertion required for metathesis of phenyl isocyanates.

One can assume that the reverse reaction of carbon dioxide with carbodiimide inserted intermediate $\mathbf{9 b}$ follows the same path to give the intermediate $\mathbf{8 b H H}$. In this case, the process $\mathbf{8 b H H} \rightarrow \mathbf{9 b}$ is energetically more costly for $\mathrm{Ti}$ compared to $\mathrm{Zr}$. Hence the metathesis of carbon dioxide is also better with $\mathrm{Zr}$ than with Ti. The computational result suggests that thermodynamic stabilities of intermediates are responsible for the experimental outcome.

\section{Conclusions}

The metathesis reaction of heterocumulenes has been carried out with zirconium(IV) $n$-butoxide and titanium (IV) $n$-butoxide and the former was found to be the most efficient catalyst. This is due to the fact that at elevated temperatures, double insertion which takes place in a head-to-head fashion is more favoured for zirconium(IV) alkoxide compared to titanium(IV) alkoxide. Computational studies carried out at the
B3LYP/LANL2DZ level attribute the observed difference in reactivity between $\mathrm{Ti}$ and $\mathrm{Zr}$ to the energetics of the reaction. These calculations have also been helpful in explaining the reversal of preferences for both $\mathrm{Zr}$ and $\mathrm{Ti}$ towards double insertion at room temperature and at elevated temperature.

\section{Supporting information}

Total energies in a. u. at B3LYP/LANL2DZ level of theory, energy and cartesian co-ordinates of atoms in each structure are given in the website (http://www.ias.ac.in/chemsci).

\section{Acknowledgements}

AGS thanks the Department of Science and Technology (DST) for the award of a research grant and AK gratefully acknowledges a senior research fellowship from Council of Scientific and Industrial Research (CSIR) and a PDF from Indian Institute of Science (IISc). Authors also thank Prof. ED Jemmis, Susmita De and Shrabani Dinda for their valuable suggestions with Gaussian calculations. We thank DST, New Delhi, for providing us funds through its FIST program for purchase of a $400 \mathrm{MHz}$ NMR spectrometer.

\section{References}

1. (a) Weiss K and Kindl P 1984 Angew. Chem. 96 616; (b) Weiss K 1984 Stud. Surf. Sci.Catal. 19 397; (c) Meisel I, Hertel G and Weiss K 1986 J. Mol. Catal. 36 159; (d) Weiss K and Hoffmann K 1987 Z. Naturforsch. 42b 769; (e) Holland A W and Bergman R G $2002 J$. Am. Chem. Soc. 1249010

2. (a) Birdwhistell K R, Boucher T, Ensminger M, Harris S, Johnson M and Toporek S 1993 Organometallics 12 1023; (b) Babcock J R and Sita L R $1998 \mathrm{~J}$. Am. Chem. Soc. 120 5585; (c) Babcock J R, Incarvito C, Rheingold A L, Fettinger J C and Sita L R 1999 Organometallics 18 5729; (d) Babcock J R, Liable-Sands L, Rheingold A L and Sita L R (1999) Organometallics 184437

3. Delaet D L, Fanwick P E and Kubiak C P 1987 J. Chem. Soc. Chem. Commun. 1412

4. (a) Kim W Y, Chang J S, Park S E, Ferrence G and Kubiak C P 1998 Chem. Lett. 1063; (b) Kim W Y, Chang J S, Park S E and Kubiak C P 1999 Res. Chem. Intermed. 25 459; (c) Sita L R, Babcock J R and Xi R 1996 J. Am. Chem. Soc. 118 10912; (d) Xi R and Sita L R 1998 Inorg. Chim. Acta 270 118; (e) Ghosh R and Samuelson A G 2005 Chem. Commun. 1152017

5. Bart S C, Anthon C, Heinemann F W, Bill E, Edelstein N M and Meyer K 2008 J. Am. Chem. Soc. 13012536 
6. (a) Ghosh R, Nethaji M and Samuelson A G $2005 \mathrm{~J}$. Organomet. Chem. 690 1282; (b) Kumar A, De S, Samuelson A G and Jemmis E D 2008 Organometallics 27955

7. (a) Pavan Kumar P N V and Jemmis E D 1988 J. Am. Chem. Soc. 110 126; (b) Jemmis E D and Giju K T 1997 Angew. Chem. Int. Ed. Engl. 36 606; (c) Jemmis E D and Giju K T 1998 J. Am. Chem. Soc. 120 6952; (d) Jemmis E D, Phukan A K and Giju K T 2002 Organometallics 212254

8. (a) Appel R, Kleinstueck R and Ziehn K D 1971 Chem. Ber. 104 1335; (b) McGhee W, Riley D, Christ K, Pan Y and Parnas B 1995 J. Org. Chem. 60 2820; (c) Wong S -W and Frisch K C 1986 J. Polym. Sci. Part A: Polym. Chem. 242867

9. (a) Becke A D 1993 J. Chem. Phys. 98 5648; (b) Becke A D 1988 Phys. Rev. A 38 3098; (c) Lee C, Yang W and Parr R G 1988 Phys. Rev. B 37785

10. (a) Hay P J and Wadt W R 1985 J. Chem. Phys. 82 270;

(b) Wadt W R and Hay P J 1985 J. Chem. Phys. 82 284; (c) Hay P J and Wadt W R 1985 J. Chem. Phys. 82 299
11. Frisch M J, Trucks G W, Schlegel H B, Scuseria G E, Robb M A, Cheeseman J R, Montgomery Jr J A, Vreven T, Kudin K N, Burant J C, Millam J M, Iyengar S S, Tomasi J, Barone V, Mennucci B, Cossi M, Scalmani G, Rega N, Petersson G A, Nakatsuji H, Hada M, Ehara M, Toyota K, Fukuda R, Hasegawa J, Ishida M, Nakajima T, Honda Y, Kitao O, Nakai H, Klene M, Li X, Knox J E, Hratchian H P, Cross J B, Bakken V, Adamo C, Jaramillo J, Gomperts R, Stratmann R E, Yazyev O, Austin A J, Cammi R, Pomelli C, Ochterski J W, Ayala P Y, Morokuma K, Voth G A, Salvador P, Dannenberg J J, Zakrzewski V G, Dapprich S, Daniels A D, Strain M C, Farkas O, Malick D K, Rabuck A D, Raghavachari K, Foresman J B, Ortiz J V, Cui Q, Baboul A G, Clifford S, Cioslowski J, Stefanov B B, Liu G, Liashenko A, Piskorz P, Komaromi I, Martin R L, Fox D J, Keith T, Al Laham M A, Peng C Y, Nanayakkara A, Challacombe M, Gill P M W, Johnson B, Chen W, Wong M W, Gonzalez C and Pople J A 2004 Gaussian 03, Revision C.02, Gaussian, Inc., Wallingford CT 